\title{
An assessment of the effects on China's food security
}

\author{
Zhonglin Sheng1,a, Weida He2,b and Yi Yu3,c \\ 1University of Science and Technology Beijing, Beijing, P.R China \\ 2University of Science and Technology Beijing, P.R China \\ 3Civil Aviation Management Institute of China, Beijing, P.R. China \\ asheng075071@hotmail.com,bhwed@ustb.edu.cn,cyuyi@126.com
}

Keywords: food security; food industry; index system

\begin{abstract}
This paper investigates the relationship between food industry and food security. With data obtained from China Statistical Yearbook and Chinese Rural Statistical Yearbook, we use panel data covering over a decade to construct an index system for estimating the food security of China and demonstrate the food security of China has decreased year by year. Our results imply that food industrial competition and industrial development circumstance contribute to dynamic changes commonly associated with the food security. Results suggest that an increase in the agricultural investment would have much larger economic impacts on national food security. Furthermore, under some conditions, science and technology input should be taken into account.
\end{abstract}

\section{Introduction}

Global food security has been a topic around many international agencies, organizations, and governments in the last decade [1]. With the progress of science and technology, the high-speed improvement of China's economy- averaging 9.1\% per year for 35 years since 1978 has many implications for China's domestic food and agriculture sector [2]. As for China, food security is not only an agricultural, economic, or public health issue, but also an important social problem regarding domestic and international implications [3].

The world Food Summit defined food security as, "Food security is a situation that exists when all people, at all times, have physical, social and economic access to sufficient, safe and nutritious food that meets their dietary needs and food preferences for an active and healthy life." [4]This definition highlights the four important dimensions of food security: access, availability, utilization and stability. Sen estimated that food security has been broadened beyond notions of food supply[5]. Amrita argued that part of the complexity of measuring and achieving a state of global good security is due to its wide definition and scope [6]. Shida showed that emerging countries have played a significant role in increasing global good availability in the past decade [7]. They found that as they have increased their agricultural production in order to meet their growing demand, fast increases in food supplies in emerging countries have raised concerns regarding social and environmental impacts. Brown reported that from 2003 to 2012, the share of Brazil, Russia, India, China and South Africa in the world GDP grew from $9 \%$ to 21\% [8]. China itself tripled its own contribution from $4 \%$ to $12 \%$. Yet, some scholars such as Brown, Gale and Coleman state that China's food security issues are different from other large developing nations such as India in that the rest of the world seems to watch China more carefully and more critically, at the least because of the potential effect of China's imports on global prices, but also possibly because of China's meteoric rise to the world stage. 
In this paper, we estimate the relationship between the food industry and food security using a panel dataset that spans over a decade. We compare determinants of national food security across three lead food industry: industrial competition, industrial development circumstance and industrial foreign interdependence. Our objective is to understand the factors that drive food insecure.

\section{Conceptual framework}

Food security is a complex and multi-dimensional concept and Food and Agriculture Organization(FAO) proposes a host of indicators to measure its four dimensions---availability, access, utilization and stability[9]. In order to measure the food industry security, we need to quantify the quantification index of industry operation which represents the security situation. Considering the complexity of food security, it is inaccuracy to measure the food industrial security only by one parameter[10]. So we try to synthetically take various factors into the measurement of the industry security.

In terms of systematization, relevance, measurability and controllability principle, this article constructs an index system for estimating the food industry security by synthetically referencing the research findings of the estimation index of food industry security we already have. (As shown in table 1)

Table 1 An index system and explanation for estimating the food industry security

\begin{tabular}{|c|c|c|c|}
\hline Estimation subject & Name of index & $\begin{array}{l}\text { Explanation or methods of } \\
\text { calculating } \\
\text { of the index }\end{array}$ & Meaning of the index \\
\hline \multirow{8}{*}{$\begin{array}{l}\text { industrial } \\
\text { development } \\
\text { circumstance }\end{array}$} & Capital cost & $=$ The fund-raising real interest rates & $\begin{array}{l}\text { Reflects collection and } \\
\text { use capital price }\end{array}$ \\
\hline & $\begin{array}{l}\text { The proportion of } \\
\text { the specialized } \\
\text { middle school and } \\
\text { above years of } \\
\text { schooling } \\
\text { population in rural } \\
\text { family }\end{array}$ & $\begin{array}{l}\text { Explanation: From "Rural residents } \\
\text { level of education" in 《Statistical } \\
\text { Yearbook of China's rural areas》[11] }\end{array}$ & $\begin{array}{c}\text { Reflects the quality of } \\
\text { agricultural labor }\end{array}$ \\
\hline & $\begin{array}{l}\text { Average per } \\
\text { person hourly pay } \\
\text { of agricultural } \\
\text { labor }\end{array}$ & $\begin{array}{c}=\text { The average pay of agricultural } \\
\text { staff/12/160 }\end{array}$ & $\begin{array}{l}\text { Reflects the cost of } \\
\text { agricultural labor }\end{array}$ \\
\hline & \begin{tabular}{|c|} 
Average per \\
person cultivated \\
area \\
\end{tabular} & $\begin{array}{c}=\text { Cultivated area/Quantity of } \\
\text { population }\end{array}$ & $\begin{array}{l}\text { reflects land element } \\
\text { condition }\end{array}$ \\
\hline & $\begin{array}{l}\text { Effective irrigated } \\
\text { area in the unit } \\
\text { cultivated area } \\
\end{array}$ & $\begin{array}{c}=\text { Effective irrigated area /Cultivated } \\
\text { area }\end{array}$ & $\begin{array}{l}\text { Reflects the level of } \\
\text { farmland irrigation }\end{array}$ \\
\hline & $\begin{array}{c}\text { Food demand rate } \\
\text { of increment }\end{array}$ & $\begin{array}{l}\text { Explanation: forecast according to } \\
\text { economic growth and the } \\
\text { population[12] }\end{array}$ & $\begin{array}{c}\text { Reflects the promoting } \\
\text { effect to production } \\
\text { owing to food demand }\end{array}$ \\
\hline & $\begin{array}{c}\text { Food commodity } \\
\text { rate }\end{array}$ & $\begin{array}{c}=\text { Average per person food sell } \\
\text { measures in rural inhabitant }\end{array}$ & $\begin{array}{c}\text { Reflects the food } \\
\text { marketability degree }\end{array}$ \\
\hline & Food reserves rate & $\begin{array}{l}\text { Explanation: this target data uses the } \\
\text { concerned experts' estimate, because } \\
\text { our country does not have the food }\end{array}$ & $\begin{array}{l}\text { Reflects the ability of } \\
\text { resisting the food } \\
\text { supply and demand }\end{array}$ \\
\hline
\end{tabular}




\begin{tabular}{|c|c|c|c|}
\hline & & margin public statistical data & unbalanced risk \\
\hline \multirow{7}{*}{$\begin{array}{l}\text { industrial } \\
\text { competition }\end{array}$} & $\begin{array}{l}\text { Industrial world } \\
\text { market share }\end{array}$ & $\begin{array}{l}\text { Domestic volume of food } \\
\text { exports/World volume of food } \\
\text { exports }\end{array}$ & $\begin{array}{l}\text { Reflects the } \\
\text { competition condition } \\
\text { of the industry in the } \\
\text { world market }\end{array}$ \\
\hline & $\begin{array}{c}\text { Industrial } \\
\text { domestic market } \\
\text { share }\end{array}$ & $\begin{array}{c}\text { (Domestic consumption } \\
\text { quantity - Volume of } \\
\text { imports)/Domestic consumption } \\
\text { quantity }\end{array}$ & $\begin{array}{l}\text { Reflects the } \\
\text { competition condition } \\
\text { of the industry in the } \\
\text { domestic market }\end{array}$ \\
\hline & $\begin{array}{l}\text { Competitive } \\
\text { advantage index }\end{array}$ & $\begin{array}{l}=(\text { Volume of food exports-Volume } \\
\text { of food imports }) /(\text { Volume of food } \\
\text { exports + Volume of food imports })\end{array}$ & $\begin{array}{c}\text { Reflects the } \\
\text { competitive advantage } \\
\text { of food industry }\end{array}$ \\
\hline & \begin{tabular}{|c|} 
Agricultural \\
scientific research \\
input
\end{tabular} & $\begin{array}{c}=\text { The amount of agricultural special } \\
\text { project funds for } \mathrm{S} \& \mathrm{~T} / \mathrm{Total} \\
\text { agricultural output value }\end{array}$ & $\begin{array}{l}\text { Reflects the agriculture } \\
\text { science and technology } \\
\text { input condition }\end{array}$ \\
\hline & Labor productivity & $\begin{array}{l}=\text { Total agricultural output value } \\
\text { Agricultural labor force population }\end{array}$ & $\begin{array}{c}\text { Reflects the } \\
\text { input-output benefits of } \\
\text { the factors of labor } \\
\text { force }\end{array}$ \\
\hline & Land productivity & $=$ Food yield / Food sown area & $\begin{array}{c}\text { Reflects the } \\
\text { input-output benefits of } \\
\text { the factors of land }\end{array}$ \\
\hline & $\begin{array}{c}\text { Production } \\
\text { concentration } \\
\text { degree } \\
\end{array}$ & $\begin{array}{l}=\text { Average per household food sown } \\
\text { area }=\text { Food sown area / Number of } \\
\text { rural households }\end{array}$ & $\begin{array}{c}\text { Reflects the } \\
\text { formalization degree of } \\
\text { food production }\end{array}$ \\
\hline \multirow{3}{*}{$\begin{array}{l}\text { Industrial foreign } \\
\text { interdependence }\end{array}$} & $\begin{array}{l}\text { Industrial import } \\
\quad \text { foreign } \\
\text { interdependence }\end{array}$ & $\begin{array}{l}=\text { Food import volume / Food } \\
\text { ultimate output }\end{array}$ & $\begin{array}{l}\text { Reflects the influence } \\
\text { size to the industry } \\
\text { from transnational } \\
\text { factors }\end{array}$ \\
\hline & $\begin{array}{l}\text { Industrial export } \\
\text { foreign } \\
\text { interdependence }\end{array}$ & $\begin{array}{l}=\text { Food export volume/ Food ultimate } \\
\text { output }\end{array}$ & $\begin{array}{c}\text { Reflects the influence } \\
\text { size to the industry } \\
\text { from transnational } \\
\text { factors }\end{array}$ \\
\hline & $\begin{array}{l}\text { Food degree of } \\
\text { self-sufficiency }\end{array}$ & $\begin{array}{l}=\text { Food ultimate output /Food total } \\
\text { demand }\end{array}$ & $\begin{array}{l}\text { Reflected the ability } \\
\text { that food production } \\
\text { satisfies the domestic } \\
\text { demand }\end{array}$ \\
\hline
\end{tabular}

\section{Methodology}

For the empirical analysis of food industry security, we do research on methods of economics security and economics early warning system, and divide the whole index system into three parts: construction of the index, early warning system and synthesis estimation. There are four index security states: safe, almost safe, unsafe and crisis. The corresponding security ranking is A, B, C and $\mathrm{D}$ respectively. The bigger score becomes, the higher the risk is.

The statistical materials used in our warning system come from "China statistical yearbook" and "The Chinese rural statistical yearbook". According to various index data, we calculate the 
security status warning scope according to various index data, overseas index of correlation's data and world average included. Further based on broad survey and expert grading, the results are shown in table 2. (Because of the limitation of space, detail process is omitted).

Table 2 Estimation indexes' forecast data list

\begin{tabular}{|c|c|c|c|c|c|c|c|c|c|}
\hline Year & $\begin{array}{c}\text { Capital } \\
\text { cost }\end{array}$ & \begin{tabular}{|c|} 
The \\
proportion \\
of the \\
specialize \\
d middle \\
school \\
and above \\
years of \\
schooling \\
population \\
in rural \\
family \\
\end{tabular} & $\begin{array}{l}\text { Average } \\
\text { per } \\
\text { person } \\
\text { hourly } \\
\text { pay of } \\
\text { agricultu } \\
\text { ral labor }\end{array}$ & $\begin{array}{l}\text { Average } \\
\text { per } \\
\text { person } \\
\text { cultivate } \\
\text { d area }\end{array}$ & $\begin{array}{l}\text { Effective } \\
\text { irrigated } \\
\text { area in } \\
\text { the unit } \\
\text { cultivate } \\
\text { d area }\end{array}$ & $\begin{array}{c}\text { Food } \\
\text { demand } \\
\text { rate of } \\
\text { increment }\end{array}$ & $\begin{array}{c}\text { Food } \\
\text { commodity } \\
\text { rate }\end{array}$ & $\begin{array}{c}\text { Food } \\
\text { reserves } \\
\text { rate }\end{array}$ & $\begin{array}{c}\text { Industria } \\
1 \text { world } \\
\text { market } \\
\text { share }\end{array}$ \\
\hline 2006 & 6.33 & 3.27 & 4.2 & 0.1 & 43.4 & 0.80 & 21.2 & & 3.19 \\
\hline 2007 & 6.33 & 3.45 & 4.5 & 0.1 & 43.9 & 0.80 & 2 & 37.3 & 3.30 \\
\hline 2008 & 6.33 & 3.63 & 4.7 & 0.1 & 44.3 & 0.79 & & 36.5 & 3.42 \\
\hline 2009 & 6.33 & 3.81 & 4.9 & 0.1 & 44.8 & 0.78 & 23 & 35.4 & 3.55 \\
\hline 2010 & 6.33 & 3.99 & 5.1 & 0.09 & 45.6 & 0.80 & 23.6 & 34.6 & 3.67 \\
\hline 2011 & 7.3 & 4.17 & 5.4 & 0.09 & 46 & 0.79 & 24.2 & 33.7 & 3.81 \\
\hline 2012 & 7.3 & 4.34 & 5.6 & 0.09 & 46.5 & 0.76 & 24.8 & 32.9 & 3.94 \\
\hline 2013 & 7.3 & 4.52 & 5.8 & 0.09 & 46.9 & 0.68 & 25 & 32.1 & 4.08 \\
\hline 2014 & 7.3 & 4.7 & 6 & 0.09 & 47.4 & 0.67 & 26.0 & 31.3 & 4.23 \\
\hline 2015 & 3 & 4.88 & 6.3 & 0.09 & 47.8 & 0.66 & 26 & 30 & 4.38 \\
\hline Year & $\begin{array}{l}\text { Industria } \\
\text { domestic } \\
\text { market } \\
\text { share }\end{array}$ & $\mid \begin{array}{c}\text { Competiti } \\
\text { ve } \\
\text { advantage } \\
\text { index }\end{array}$ & \begin{tabular}{|} 
Agricult \\
ural \\
scientific \\
research \\
input \\
\end{tabular} & $\begin{array}{c}\text { Labor } \\
\text { producti } \\
\text { vity }\end{array}$ & $\begin{array}{c}\text { Land } \\
\text { producti } \\
\text { vity }\end{array}$ & \begin{tabular}{|c|} 
Productio \\
$\mathrm{n}$ \\
concentra \\
tion \\
degree
\end{tabular} & \begin{tabular}{|c|} 
Industrial \\
import \\
foreign \\
interdepend \\
ence
\end{tabular} & \begin{tabular}{|c|} 
Industria \\
export \\
foreign \\
interdepend \\
ence
\end{tabular} & \begin{tabular}{|c|} 
Food \\
degree \\
of self \\
-sufficie \\
ncy
\end{tabular} \\
\hline 2006 & & -0.53 & 0.044 & 11874.9 & 4624.16 & 0.404 & 5.62 & 3.28 & 94.5 \\
\hline 2007 & 94.4 & -0.56 & 0.046 & 12479.4 & 4663.74 & 0.397 & 5.97 & 3.44 & 93.9 \\
\hline 2008 & 94.1 & -0.58 & 0.048 & 13083.8 & 4703.33 & 0.39 & 6.34 & 3.60 & 93.3 \\
\hline 2009 & 93.8 & -0.60 & 0.05 & 13688.3 & 4742.92 & 0.384 & 6.73 & 3.78 & 92.8 \\
\hline 2010 & 93.4 & -0.62 & 0.051 & 14292.8 & 4782.5 & 0.377 & 7.15 & 3.95 & 92.2 \\
\hline 2011 & 93.0 & -0.64 & 0.053 & 14897.3 & 4822.09 & 0.371 & 7.60 & 4.14 & 91.6 \\
\hline 2012 & 92.6 & -0.66 & 0.055 & 15501.7 & 4861.68 & 0.364 & 8.07 & 4.34 & 91.1 \\
\hline 2013 & 92.2 & -0.67 & 0.057 & 16106.2 & 4901.27 & 0.357 & 8.57 & 4.55 & 90.6 \\
\hline 2014 & 91.8 & -0.69 & 0.059 & 16710.7 & 4940.85 & 0.351 & 9.10 & 4.76 & 90.2 \\
\hline 2015 & 91.3 & -0.71 & 0.061 & 17315.2 & 4980.44 & 0.344 & 9.67 & 4.99 & 89.7 \\
\hline
\end{tabular}

Our processing step is to calculate score value of qualitative index according to the index value's security state and its degree. Regarding the quantitative index, there are several kinds of situations:

1. If the index's security status decreased with its value, the following formula can be mapped on to the corresponding score in accordance with index security state: 
$F_{i j}=$ score lower limit

$$
+(\text { index value }- \text { upper warning limit }) \times \frac{\text { score } \text { upper limit }- \text { score lower limit }}{\text { upper warning limit }- \text { lower warning limit }}
$$

In this formula, Fij is the score of index; the score upper limits and limits are of great importance to the security state of Sij , for example, defining score limits between 20 to 50 as "almost safe"; defining "crisis" as score vary from 80 to 100, then warning limits and index value can deter the security state of $\mathrm{Sij}$.

2. If the index's security status increased with value, the following formula can be mapped the corresponding score on to security state:

$F_{i j}=$ score upper limit

$$
+(\text { index value }- \text { lower warning limit }) \times \frac{\text { score upper limit }- \text { score lower limit }}{\text { upper warning limits }- \text { lower warning limit }}
$$

3. If a satiety point existed. The farther from the point, the less security it is. For this situation, the following formula can be mapped the corresponding score on to security state:

When the index is at the safe state, the formula is:

$$
\begin{gathered}
F_{i j}=2 \times \mid \text { index value }-\frac{\text { upper warning limit }+ \text { lower warning limit }}{2} \mid \\
\times \frac{\text { score upper limit }- \text { score lower limit }}{\text { upper warning limit }- \text { lower warning limit }}
\end{gathered}
$$

When the index is at the unsafe status, there are two situations:

when the index security status increased with value, the formula is: $F_{i j}=$ score upper limit

$$
\text { -(index value }- \text { lower warning limit) } \times \frac{\text { score upper limit }- \text { score lower limit }}{\text { upper warning limit }- \text { lower warning limit }}
$$

when the index security status decreased with value, the formula is: $F_{i j}=$ lower score limit

$$
\text { -(index value }- \text { lower warning limit) } \times \frac{\text { score upper limit }- \text { score lower limit }}{\text { upper warning limit }- \text { lower warning limit }}
$$

What needs to explain is, when we use the formula above to calculate the score, we must identify the maximum and the minimum of the warning limits. However, some of indexes don't have warning limits at "safe" or "crisis". For this situation, we adopt the following processing method:

1) If the index doesn't have an upper warning limit, we take two times lower warning limit as the upper warning limit. When the index value is bigger than two times lower limit, we take the index value as upper limit.

2) If the index doesn't have a lower warning limit, there are two situations: if the lower warning limit is bigger than zero, we take zero as the lower limit; if the lower warning limit is 
smaller than zero, we take two times the limits superior as the lower limit.

We set four weights of first-level index by experts grading: The weight of industrial development circumstance and industrial foreign interdependence accounts for 0.4 and 0.2 respectively. The industrial competition weight is 0.4 . We assume that the weights of second-level index are same, so we can obtain the detail weights.

By using the formula below, there is a weighted summation with the score which mapped on to index. As the result, we can obtain the overall degree of security index for the first-level index $\mathrm{Si}$ :

$$
S_{i}=\sum \frac{W_{i j} F_{i j}}{\sum W_{i j}} \quad i=\quad \mathfrak{B}
$$

In the formula, Wij is the weight of $\mathrm{Sij}$, Fij is the score of index calculated above, thus the value of $\mathrm{Si}$ is between 0 and 100 .

By using the formula below, we can obtain the overall degree of security index $\mathrm{S}$ for whole food industry.

$$
S=\sum \frac{W_{i} S_{i}}{\sum W_{i}} \quad i=1,2,3
$$

In the formula, Wi is the weight of $\mathrm{Si}$ and the value of $\mathrm{S}$ is between 0 and 100 .

\section{Estimate results}

Using the estimation model which already has been established, we estimate and evaluate China's food industry security condition between 2006 and 2015. Some models and methods, such as linear regression and gray forecast, are applied to forecast eighteen index data of food industry from 2006 to 2015 (Concrete process is omitted). As shown in table 2.

Two conclusions mark the indicates from the estimation results. The first is there are two ingredients driving China's food industry security from security to insecurity status. One is the industrial competition, and the other is industrial development circumstance. This indicates there exists a disparity in food industry between China and western developed countries in these aspects, and also contains potential risk. Moreover, with these index score increasing year by year, it means Chinese food industry security state has the possibility to get much worse. So the government must pay more attention to it. Secondly, some index scores are under the security limit, such as industrial import foreign interdependence, industrial export foreign interdependence and food degree of self-sufficiency. From above we conclude that Chinese food industry foreign interdependence is not high, and trade influence on food industry security is not so much.

\section{Conclusion}

Proceeded from the conception of food industry security, this article constructs an index system for estimating the food industry security and evaluates it of China during the period of 2006-2015. The empirical result indicates that during that time the condition of Chinese food industry develops from basic security to insecurity. After 2009, the security degree gradually exacerbated year by year. The industrial competition and industrial development circumstance are 
the key elements affecting food industry security. On the contrary, Chinese food industry foreign interdependence is not high, and international trade influence on food industry security is not much.

In the contrast with some developed countries, Chinese agricultural labor force quality is rather lower than developed countries. Therefore, it is necessary to strengthen rural labor force vocational skill training and encourage each kind of education training organization and employers to develop farmer vocational skill training.

\section{Acknowledgments}

The authors also would like to thank the financial support provided by the National Social Science Foundation of China under Grant No. 14ZDA088, the Social Science Foundation of Beijing under Grant No. 14JGA014. Authors are solely responsible for all remaining errors.

\section{References}

[1]Food and Agricultural Organization of the United Nations (FAO).:The state of food insecurity in the world: Economic growth is necessary but not sufficient to accelerate reduction of hunger and malnutrition. Rome, Italy(2012).

[2]Gregory Veeck: China's food security: past success and future challenges. Eurasian Geography and Economics, 54(1) 42-56(2013).

[3]Ahmed M., Lorica M, H.:Improving developing country food security through aquaculture development-lessons from Asia, Food Policy(27):125-141(2002).

[4]World Bank :Poverty and Hunger: Issues and Options for Food Security in Developing Countries. World Bank, Washington(1986).

[5]Sen, A.:Poverty and Famines: An Essay on Entitlement and Deprivation. Clarendon Press, Oxford(1981).

[6]Amrita Sandu:National food security act, 2013 and food security outcomes in India, Vision 18(4):365-370(2014).

[7]Shida Rastegari Henneberry and Claudia P. Diaz Carrasco:Global food security: Emerging economies and diverging food markets. Journal of Food Distribution Research: 45(1) 29-34(2014).

[8]Brown, L,R. :Full plant, empty plates,93-100. New York. NY: W.W. Norton \&Company(2012).

[9]Food and Agricultural Organization of the United Nations FAO): The states of Food insecurity in the world. Available from http://www.fao.org/docrep/018/i3434e/.

[10]Brown, L,R:Who will feed China? New York. NY:W. W. Norton\&Company(1995).

[11]Brown, J, V.:Food security for all by the year 2020? Agriculture and Rural (4):2(1997).

[12]Chamber, R.:Vulnerability, coping and policy, IDS Bulletin 20(2),1-7(1988). 